\title{
The Use of International Law by the United Nations Security Council: An Empirical Framework for Analysis
}

Rossana Deplano

Follow this and additional works at: https://scholarlycommons.law.emory.edu/eilr-recent-developments

\section{Recommended Citation}

Rossana Deplano, The Use of International Law by the United Nations Security Council: An Empirical Framework for Analysis, 29 Emory Int'I L. Rev. Recent Dev. 2085 (2015).

Available at: https://scholarlycommons.law.emory.edu/eilr-recent-developments/27

This Essay is brought to you for free and open access by the Journals at Emory Law Scholarly Commons. It has been accepted for inclusion in Emory International Law Review Recent Developments by an authorized administrator of Emory Law Scholarly Commons. For more information, please contact law-scholarlycommons@emory.edu. 


\title{
THE USE OF INTERNATIONAL LAW BY THE UNITED NATIONS SECURITY COUNCIL: AN EMPIRICAL FRAMEWORK FOR ANALYSIS
}

\author{
Rossana Deplano*
}

\begin{abstract}
This Article examines the strategic use of international law by the United Nations Security Council. Using an original database, which includes 611 resolutions adopted by the Security Council from 2004 to 2013, it provides a systematic analysis of the Security Council's behavioral patterns that may help determine significant selection preferences in the exercise of its powers under the United Nations Charter. The analysis shows that while reference to positive international law in the text of resolutions contributes to shaping the politics of the Security Council, current Security Council practice has little or no influence over the development of international law.

\section{INTRODUCTION}

Scholarly literature on the United Nations Security abounds. From an international legal perspective, existent contributions have examined several aspects of the Security Council mandate, including its scope, the legitimacy of certain Security Council actions, and its lawmaking powers. ${ }^{1}$ The contribution of such a body of literature to the rationalization of the principles of law governing the Security Council functioning is highly relevant. Nonetheless, Security Council practice has never been analyzed in a systematic way.

* LL.B, LL.M, Ph.D., Lecturer, Brunel University London (U.K.). I would like to thank Dr. Paolo Vargiu for his comments on earlier drafts and Dr. Patricia Hobbs for her constant support. All mistakes remain mine.

See, e.g., David M. Malone, Security Council, in THE OXford HANDBooK ON THE United Nations 117 (Thomas G. Weiss \& Sam Daws eds., 2008). See generally, e.g., Simon Chesterman, Thomas M. Franck, \& David M. Malone, LaW and Practice of the United Nations: Documents and Commentary (2008); Antonios Tzanakopoulos, Disobeying the SEcurity Council (2013); Sufyan Droubi, Resisting United Nations Security Council Resolutions (2014); Erika de Wet, The CHAPTER VII POWERS OF THE UNITED NATIONS SECURITY COUNCIL (2004).
\end{abstract}


Doctrinal studies have proved to be successful in conceptualizing relevant principles and rules underlying the functioning of the Security Council. ${ }^{2}$ They have also assessed the degree of compliance of selected case-studies with the provisions of the U.N. Charter and international law. ${ }^{3}$ However, due to the nature of the inquiry, traditional analysis is rooted on assumptions or generalizations derived from the study of selected, though important, Security Council decisions. Consequently, its findings are supported by little evidence of consolidated Security Council practice. For example, it has become commonplace to argue that the decision-making at the Security Council is ultimately governed by reasons of political convenience. ${ }^{4}$ The main argument put forward to support this view is that the presence of five permanent members (P5) endowed with veto power over resolutions determines that the Security Council mandate can be executed only when there is agreement among them.

As a result, situations representing actual or potential breaches of international peace and security are likely to be overlooked whenever they involve a direct interest of a P5. ${ }^{6}$ This seems to be confirmed by the fact that since 1946, not a single resolution has been adopted on Tibet or Chechnya, while only one has been adopted in 1960 on the relationship between Cuba and the United States. ${ }^{7}$ More recently, a draft resolution on Crimea has been vetoed by one P5 due to opposed views and conflicting interests with the proponent

2 See generally, Anne Peters, Functions and Powers:Article 24, in 1 THE CHARTER OF THE UNITED NATIONS: A COMMENTARY 2011 (Bruno Simma et al. eds., 2012); Nicholas Tsagourias, Security Council Legislation, Article 2(7) of the UN Charter, and the Principle of Subsidiarity, 24 LEIDEN J. INT'L L. 539 (2011); Eric Rasand, The Security Council as "Global Legislator": Ultra Vires or Ultra Innovative?, 28 Fordham INT'L L.J. 542 (2005); Munir Akram \& Syed H. Shah, The Legislative Powers of the United Nations Security Council, in TOWARDS WORLD CONSTITUTIONALISM: ISSUES IN THE LEGAL ORDERING OF THE WORLD Community 431 (Ronald St. John Macdonald \& Douglas M. Johnston eds., 2005); Axel Marschik, Legislative Powers of the Security Council, in TOWARDS WORLD CONSTITUTIONALISM: ISSUES IN THE LEGAL ORDERING OF THE World COMMUNity 457 (Ronald St. John Macdonald \& Douglas M. Johnston eds., 2005); Cathleen Powell, The Legal Authority of the United Nations Security Council, in SECURITY AND Human Rights 157 (Benjamin J. Goold \& Liora Lazarus eds., 2007); BARdo FASSBENDER, THE United NATIONS CHARTER AS CONSTITUTION OF THE INTERNATIONAL COMMUNITY (2009).

3 See generally, e.g., Christian Henderson \& Noam Lubell, The Contemporary Legal Nature of UN Security Council Ceasefire Resolutions, 26 LEIDEN J. INT'L L. 369 (2013).

4 See, e.g., Michael Barnett \& Martha Finnemore, Political Approaches, in THE OXFord HANDBOOK ON THE UNITED NATIONS, supra note 1 , at 41 .

5 Nigel Rodley \& Başak Çali, Use of Force in International Law, in INTERNATIONAL LAW FOR INTERNATIONAL RELATIONS 226 (Başak Çali ed., 2010).

6 See id.

7 S.C. Res. 144, U.N. Doc. S/4395 (July 19, 1960). 
P5. ${ }^{8}$ However, as of today no study has ever provided a detailed list of the issues addressed in the resolutions adopted, resolutions vetoed, Security Council private meetings, and meetings concluded with no action, with a view to ascertain the overall degree of legitimacy and effectiveness of such actions.

The present study aims at addressing this knowledge gap. It reports evidence from a substantial and systematic quantitative study designed to examine a sample of Security Council decisions which is representative of current Security Council practice, within a limited time-frame. The research is complementary to the existing body of literature since it introduces an empirical framework of analysis. Using an original database, which includes 611 resolutions adopted by the Security Council between 2004 and 2013, the research aims to establish the extent to which, if any, international law is able to limit the discretionary powers of the Security Council, and how the behavioral patterns of the Security Council contribute to the creation or development of international law. The findings of the analysis show that the Security Council has developed a self-contained legal mind under the aegis of the U.N. Charter, and that this evolutionary process poses a threat to the legitimacy of recent Security Council practice.

The remainder of the article is organized as follows. Part II provides a brief overview of the normative background of the Security Council, which represents the backdrop against which to evaluate the empirical analysis. Part III introduces the empirical framework for assessing Security Council practice. The first sub-section outlines the research design. The second one examines the extent to which the Security Council relies upon international law. Its purpose is to single out which rules of international law have been used by the Security Council in its resolutions and how they interact with each other. Part IV discusses the empirical results and their legal implications. It seeks to establish a taxonomy of Security Council decisions with a view to finding significant selection effects. Part V concludes.

\section{OVERVIEW OF SECURITY COUNCIL POWERS}

Chapter VII of the U.N. Charter confers the responsibility for the maintenance of "international peace and security" on the Security Council.

8 U.N. Security Council action on Crimea referendum blocked, U.N. NEwS CENTRE (Mar. 15, 2014), http://www.un.org/apps/news/story.asp?NewsID=47362\#.VNE-dGQbDTE (referring to S.C. Draft Res. 189, U.N. Doc. S/2014/189 (Mar. 14, 2014)).

9 U.N. Charter art. 39. 
The U.N. Charter, however, does not provide for a definition of international peace and security, thus leaving the power to determine its significance to the judgment of the Security Council itself. ${ }^{10}$ In order to execute its mandate, the Security Council disposes of a wide range of powers, including "the powers to authorize the use of force in the name of the international community." According to the established doctrine of implied powers, the Security Council also possesses those powers that are essential for the performance of its duties and that are commensurate with its responsibility for the maintenance of international peace and security. ${ }^{12}$ Thus Security Council resolutions imposing obligations to the international community of states as a whole rather than being restricted to U.N. members are regarded as a direct emanation of the teleological reading of U.N. powers in general, and Security Council powers in particular. ${ }^{13}$

With regard to the internal functioning of the Security Council, its decision-making power is governed by a combination of provisions of the U.N. Charter, ${ }^{14}$ provisions of the Provisional Rules of Procedure complementing the text of the U.N. Charter, ${ }^{15}$ and other documents such as Note 507, complementing the Provisional Rules of Procedures. ${ }^{16}$ This set of rules allows the Security Council to adopt a variety of decisions, including resolutions, PRSTs, notes by the Security Council President, press statements and letters from the Security Council President. ${ }^{17}$ Although the list is not exhaustive, resolutions are recognized as the type of Security Council decision endowed

10 See id.

11 Rodley \& Çali, in INTERNATIONAL LAW FOR INTERNATIONAL RELATIONS, supra note 5, at 225.

12 See Reparation for Injuries Suffered in the Service of the United Nations, Advisory Opinion, 1949 I.C.J. 174, 178 (Apr. 11); Legal Consequences for States of the Continued Presence of South Africa in Namibia (South West Africa) Notwithstanding Security Council Resolution 276, Advisory Opinion, 1971 I.C.J. 16, ๆ 109 (June 21).

13 Tsagourias, supra note 2, at 545-47. See generally, S.C. Res. 1373, U.N. Doc. S/RES/1373 (Sept. 28, 2001); S.C. Res. 1540, U.N. Doc. S/RES/1540 (Apr. 28, 2004); S.C. Res. 1636, U.N. Doc. S/RES/1636 (Oct. 31, 2005); S.C. Res. 1701, U.N. Doc. S/RES/1701 (Aug., 11, 2006); S.C. Res. 1737, U.N. Doc. S/RES/1737 (Dec. 27, 2006); S.C. Res. 1803, U.N. Doc. S/RES/1803 (Mar. 3, 2008).

14 U.N. Charter arts. 27, 31-32.

15 U.N. S.C., Provisional Rules of Procedure of the Security Council, rules 40-57, U.N. Doc. S/96 (June 27, 1946).

16 U.N. S.C. Pres., Note by the President of the Security Council, para. 2, U.N. Doc. S/2010/507 (July 26, 2010) [hereinafter Note 507]. For further analysis on procedural aspects of the Security Council decision making, see Rossana Deplano, Building a Taxonomy of United Nations Security Council Decisions: A Biased Compliance with the UN Charter Obligations?, 1 ST. PRAC. \& INT'L L.J. 143 (2014).

17 United Nations, The Security Council Working Methods HandBooK 90 (2012). 
with the greatest political relevance because they must be obeyed by U.N. member states. ${ }^{18}$

The element of compulsion characterizing resolutions, along with the existence of the P5's veto power, determines that attributing meaning to the words of the U.N. Charter "international peace and security"19 is an act of discretion exercised by the Security Council. More specifically, since individual resolutions of the Security Council do not set a precedent, what constitutes a threat to or breach of international peace and security is ultimately determined by the willingness of individual permanent members to take a specific action or inaction on a case-by-case basis. On this ground, the Security Council has been severely criticized as a non-representative and highly politicized body whose actions have not always been either efficient or impartial. ${ }^{20}$ The presence of the P5, in particular, is seen as anachronistic and has triggered a debate on the need to reform the Security Council to keep the pace with the changes currently taking place within the international community. ${ }^{21}$ The perceived fear is that as long as no superior organ to the Security Council exists, the P5 can yield unrestricted powers which, albeit formally subject to the purposes and principles of the U.N. Charter, ${ }^{22}$ cannot in fact be controlled by either the United Nations or its member states. The result is that each P5 is able to transpose important elements of its foreign policy to the international plane without the need to justify it under international law.

\section{ANAlysis of SeCURITy COUNCIL PRACTICE (2004-2013)}

\section{A. Research Design}

Empirical scholarship on Security Council practice is still in its infancy. ${ }^{23}$ Existent contributions have built a taxonomy of Security Council decisions with a view to finding significant selection effects. ${ }^{24}$ Scholars have then used

18 See Andreas Zimmerman, Voting: Article 27, in THE Charter of THE United NATIONS: A COMMENTARY, supra note 2, at 1820 (Bruno Simma et al. eds., 2012). On the interpretation of Security Council resolutions, see generally Alexander Orakhelashvili, The Acts of the Security Council: Meaning and Standards of Review, 11 MaX PLANCK Y.B. U.N. L. 143 (2007).

19 U.N. Charter, art. 11, para 3.

20 Rodley \& Çali, in INTERNATIONAL LAW FOR INTERNATIONAL RELATIONS supra note 5, at 228.

21 CHESTERMAN ET AL., supra note 1, at 133.

22 See Certain Expenses of the United Nations (Article 17, Paragraph 2, of the Charter), Advisory Opinion, 1962 I.C.J. 151, 167-68 (July 20).

23 Deplano, supra note 16, at 139-41.

24 Id. at 139. 
the results of the empirical analysis as a platform to assess the degree of compliance of Security Council decisions with international human rights standards. ${ }^{25}$ This study provides a deeper understanding of the rationale behind the adoption of Security Council decisions. By mapping the rules and principles of international law referred to in the text of Security Council resolutions, the proposed analysis attempts to conceptualize the legal mind of the Security Council.

The basis of the present research is quantitative and consists in coding and analyzing 611 resolutions adopted by the Security Council in the period of time between 2004 and 2013. The full text of resolutions is reported in the Security Council Annual Report to the General Assembly, which gathers all the questions considered by the Security Council during the year, as well as in the digital archive developed in 1995 by the U.N. Department of Public Information, which is freely available and provides direct access, via hypertext links, to each Security Council resolution since $1946 .{ }^{26}$

The research methodology adopted is based on the textual analysis of a sample of resolutions representative of current Security Council practice. In order to establish the extent to which international law influences the politics of the Security Council and vice versa, an original database has been created. The coding method is organized in two parts. Firstly, to identify and classify existent categories of Security Council resolutions, individual resolutions have been grouped into different categories by using the descriptive formulation provided for all resolutions in the digital archive of the Security Council. Secondly, for each category of resolutions, two types of relevant rules have been identified. They include provisions of international law expressly mentioned in the text of resolutions, and principles developed by the Security Council which are not supported by positive international law.

As discussed below, the findings show that the overwhelming majority of Security Council resolutions address actual or potential breaches of international peace and security taking place in specific geopolitical regions, while the remaining ones regulate general issues variously related to the legitimacy of Security Council actions.

25 See generally, e.g., Paolo Vargiu \& Rossana Deplano, The Human Rights Dimension of UN Security Council Resolutions, in Essays on Human Rights: A CElebration OF the Life of Dr. Janusz KoCHANOWSKi 523 (Jo Carby-Hall ed., 2014).

26 Security Council Resolutions, UNITED NATIONS, www.un.org/en/sc/documents/resolutions/ (last visited Feb. 6, 2015). 


\section{B. Security Council and International Law: A Conceptual Map}

This Section examines the extent to which the Security Council relies upon international law. It shows evidence of the type of international legal instruments referred to in the text of resolutions. Such instruments have been divided into two groups. They include U.N. documents such as Security Council resolutions, PRSTs, General Assembly resolutions, and reports of the Secretary-General on one hand, and primary sources, such as treaties and customary international law (CIL) on the other hand. The analysis also considers generic reference to international law, including international humanitarian law, international human rights law, refugee law, and international standards.

Sometimes the same source is cited more than once in the same paragraph of a resolution. For the purpose of this study, only the first citation is taken into account. Furthermore, since the inquiry is restricted to evaluating the use of international legal instruments by the Security Council, generic reference to human rights or the rule of law is not reported.

The overall results show that the majority of citations concern U.N. documents in general and Security Council resolutions in particular. The latter are equally divided between resolutions on the same subject-matter of the resolution under scrutiny, and resolutions addressing related topics. Re-cited Security Council resolutions are often accompanied by reference to related PRSTs. In general, the Preamble contains a higher number of citations than the operative part of resolutions.

The most cited sets of resolutions address thematic issues-namely, women and peace and security, children in armed conflict, and protection of civilians in armed conflicts. Although merely declaratory, ${ }^{27}$ such resolutions and related PRSTs appear to have gained a special status among the sample of Security Council resolutions examined. Conversely, the resolutions on admissions of new members to the United Nations, those providing recommendations for the appointment of the new Secretary-General, those establishing a date of election to fill a vacancy in the International Court of Justice (ICJ), and the one providing a tribute to the outgoing Secretary-General do not contain any reference to international legal documents.

27 Declaratory Security Council resolutions and PRSTs are of quasi-legislative nature and have no normative effect. See Tsagourias, supra note 2, at 540. 
In a number of instances, compliance with relevant Security Council resolutions is required in absolute terms. ${ }^{28}$ Whether this consolidated practice constitutes a precedent, at least with regard to resolutions referring to previous Security Council resolutions on the same subject-matter, ${ }^{29}$ is contested, although the answer seems to be negative. ${ }^{30}$ Likewise, re-cited Security Council resolutions do not appear to contribute to the creation or development of CIL. ${ }^{31}$ However, with regard to the legal force of resolutions, they stay on an equal footing with primary sources of international law. A passage from Security Council resolution 2087(2013), for example, reads: "Recognizing the freedom of all States to explore and use outer space in accordance with international law, including restrictions imposed by relevant Security Council resolutions." 32 Nonetheless, certain treaty provisions are recognized as the standard of international legality and might be successful in mitigating, to a certain extent, the discretionary powers of the Security Council. Prominent examples are the Treaty of Non-Proliferation of Nuclear Weapons (NPT), ${ }^{33}$ the U.N. Convention on the Law of the Sea (UNCLOS), ${ }^{34}$ the Geneva Conventions, ${ }^{35}$ and the purposes and principles of the U.N. Charter. ${ }^{36}$

28 S.C. Res. 1887, para. 10, U.N. Doc. S/RES/1887 (Sept. 24, 2009); S.C. Res. 1894, paras. 1, 6, U.N. Doc. S/RES/1894 (Nov. 11, 2009); S.C. Res. 1904, para. 44, U.N. Doc. S/RES/1904 (Dec. 17, 2009); S.C. Res. 1963, para. 17, U.N. Doc. S/RES/1963 (Dec. 20, 2010); S.C. Res. 2009, para. 11, U.N. Doc. S/RES/2009 (Sept. 16, 2011); S.C. Res. 2035, para. 15, U.N. Doc. S/RES/2035 (Feb. 17, 2012); S.C. Res. 2068, para. 1, U.N. Doc. S/RES/2068 (Sept. 19, 2012); S.C. Res. 2075, para. 2, U.N. Doc. S/RES/2075 (Nov. 16, 2012); S.C. Res. 2104, para. 5, U.N. Doc. S/RES/2104 (May 29, 2013); S.C. Res. 2126, para. 6, S/RES/2126 (Nov. 25, 2013).

29 S.C. Res. 1882, pmbl., U.N. Doc. S/RES/1882 (Aug. 4, 2009); S.C. Res. 1929, paras. 6, 16, U.N. Doc. S/RES/1929 (June 9, 2010); S.C. Res. 1998, para. 9, U.N. Doc. S/RES/1998 (July 12, 2011).

30 S.C. Res. 2118, pmbl., U.N. Doc. S/RES/2118 (Sept. 27, 2013). But see S.C. Res. 1904, supra note 28, I 1 (establishing duties of compliance with previous Security Council resolutions on international terrorism for both U.N. members and non-member states).

31 S.C. Res. 1918, pmbl., U.N. Doc. S/RES/1918 (Apr. 27, 2010) ("underscoring . . that resolution 1897 shall not be considered as establishing customary international law"); see also S.C. Res. 1897, para. 8, U.N. Doc. S/RES/1897 (Nov. 30, 2009); S.C. Res. 1950, para. 8, U.N. Doc. S/RES/1950 (Nov. 23, 2010); S.C. Res. 2020, para. 10, U.N. Doc. S/RES 2020 (Oct. 12, 2011); S.C. Res. 2077, para. 13, U.N. Doc. S/RES/2077 (Nov. 21, 2012); S.C. Res. 2125, para. 13, U.N. Doc. S/RES/2125 (Nov. 18, 2013) ("underscoring that this resolution shall not be considered as establishing customary international law"); S.C. Res. 1976, pmbl., U.N. Doc. S/RES/1976 (Apr. 11, 2011); S.C. Res. 2015, pmbl., U.N. Doc. S/RES/2015 (Oct. 24, 2011).

32 S.C. Res. 2087, pmbl., U.N. Doc. S/RES/2087 (Jan. 22, 2013).

33 S.C. Res. 1887, pmbl., supra note 28 ("Underlining that the NPT remains the cornerstone of the nuclear non-proliferation regime and the essential foundation for the pursuit of nuclear disarmament and for the peaceful uses of nuclear energy, Reaffirming its firm commitment to the NPT and its conviction that the international nuclear non-proliferation regime should be maintained and strengthened to ensure its effective implementation, ...").

34 S.C. Res. 2018, pmbl., U.N. Doc. S/RES/2018 (Oct. 31, 2011) (“Affirming that international law, as reflected in the United Nations Convention on the Law of the Sea of 10 December 1982, in particular its 
The analysis also shows that particular sets of resolutions stand out either for the abundance or the paucity of the sources of international law other than United Nations documents referred to in the text of those resolutions. Resolutions on Somalia as well as those drawing on the reports of the Secretary-General on Sudan are examples of the first type. They both address situations classified as breaches of international peace and security, and represent the cusp of a trend in which Security Council resolutions addressing situations taking place in Africa rely heavily upon international legal instruments as the preferred means for eliciting compliance of their addressees. ${ }^{37}$ Most notably, the resolutions on the reports of the SecretaryGeneral on Sudan contain a well-proportioned amount of reference to sources of international law in both the Preamble and the operative part of resolutions. Sources referred to include treaties, various U.N. documents and generic reference to international law, including international humanitarian and human rights law in equal measure. ${ }^{38}$ On the other hand, the distinctive trait of resolutions on Somalia is that they are the only ones to mention CIL and, ${ }^{39}$

articles 100, 101 and 105, sets out the legal framework applicable to countering piracy and armed robbery at sea, as well as other ocean activities"); see also S.C. Res. 2125, supra note 31, pmbl.; S.C. Res. 2077, supra note 31, pmbl.; S.C. Res. 2039, pmbl., U.N. Doc. S/RES/2039 (Feb. 29, 2012); S.C. Res. 2020, supra note 31, pmbl.; S.C. Res. 2015, supra note 31, pmbl.; S.C. Res. 1976, supra note 31, pmbl.; S.C. Res. 1950, supra note 31, pmbl.; S.C. Res. 1918, supra note 31, pmbl.; S.C. Res. 1897, supra note 31, pmbl.; S.C. Res. 1851, pmbl., U.N. Doc. S/RES/1851 (Dec. 16, 2008); S.C. Res. 1846, pmbl., U.N. Doc. S/RES/1846 (Dec. 2, 2008); S.C. Res. 1838, pmbl., U.N. Doc. S/RES/1838 (Oct. 7, 2008); S.C. Res. 1816, pmbl., U.N. Doc. S/RES/1816 (June 2, 2008).

35 S.C. Res. 1894, supra note 28, pmbl. ("[T] he Geneva Conventions of 1949, which together with their Additional Protocols constitute the basis for the legal framework for the protection of civilians in armed conflict.").

36 S.C. Res. 1894, supra note 28, pmbl.; S.C. Res. 1874, pmbl., U.N. Doc. S/RES/1874 (June 12, 2009); S.C. Res. 1817, pmbl., U.N. Doc. S/RES/1817 (June 11, 2008); S.C. Res. 1688, pmbl., U.N. Doc. 1688 (June 16 2006); S.C. Res. 1645, pmbl., U.N. Doc. S/RES/1645 (Dec. 20, 2005); see also S.C. Res. 2123, U.N. Doc. S/RES/2123 (Nov. 12, 2013) (supporting resolutions on Bosnia and Herzegovina); S.C. Res. 2099, U.N. Doc. S/RES/2099 (Apr. 25, 2013) (supporting Western Sahara resolutions); S.C. Res. 1894, supra note 28 (providing protection of civilians in armed conflict).

37 See, for instance, the Resolutions on the Democratic Republic of the Congo, Ivory Coast, Mali, Peace and security in Africa, Sudan/South Sudan. S.C. Res. 2179, U.N. Doc. S/RES/2179 (Oct. 14, 2014) (South Sudan); S.C. Res. 2177, U.N. Doc. S/RES/2177 (Sept. 18, 2014) (Africa); S.C. Res. 2164, U.N. Doc. S/RES/2164 (June 25, 2014) (Mali); S.C. Res. 2153, U.N. Doc. S/RES/2153 (Apr. 29, 2014) (Ivory Coast); S.C. Res. 2147, U.N. Doc. S/RES/2147 (Mar. 28, 2014) (Dem. Rep. Congo). Contrast resolutions on Liberia and Sierra Leone. S.C. Res. 2188, U.N. Doc. S/RES/2188 (Dec. 9, 2014) (Liberia); S.C. Res. 2065, U.N. Doc. S/RES/2065 (Sept. 12, 2012) (Sierra Leone)

38 See generally U.N. Secretary-General, Report on South Sudan, U.N. Doc. S/2014/821 (Nov. 18, 2014); U.N. Secretary-General, Report on South Sudan, U.N. Doc. S/2014/537 (July 25, 2014).

39 S.C. Res. 2182, para. 21, U.N. Doc. S/RES/2182 (Oct. 24, 2014). 
contrary to the majority of Security Council resolutions under scrutiny, place more emphasis on international human rights law rather than humanitarian law.

Resolutions on Afghanistan and threats to international peace and security caused by terrorist acts pertain to the second type. Reference to international treaties is virtually absent in the latter, with the Bonn Agreement of 2005 on Afghanistan mentioned once in the Preamble to resolution 1988 (2011). ${ }^{40}$ This set of resolutions is also characterized by a continuous reference, both in the Preamble and in the operative part, to previous Security Council resolutions on Afghanistan and general issues relating to sanctions. Resolution 1904 (2009) also dictates that all States, U.N. members and non-members alike, must take the measures to combat international terrorism as imposed by previous Security Council resolutions. ${ }^{41}$ Despite sporadic reference to international law, humanitarian law, international human rights law and refugee law in the Preamble, however, it is hard to single out the parameter of legality adopted by the Security Council to justify its actions other than Security Council resolutions themselves.

On the other hand, resolutions on Afghanistan tend to supply the paucity of reference to international treaties with great attention to Security Council resolutions on women, children, and civilians as well as resolutions on threats to international peace and security caused by terrorist acts. In light of the considerations above, this suggests that only the former set of resolutionswomen, children, and civilians - may be regarded as the legal basis of Security Council actions, ${ }^{42}$ in addition to the U.N. Charter provisions establishing the Security Council mandate.

Finally, the empirical results show that two individual resolutions possess unique features. The first one is resolution 1929(2010) on nuclear nonproliferation in Iran. It stands out as the most politicized of the resolutions under scrutiny as it establishes that to restore the confidence of the international community, the strategy for resolving the Iranian nuclear issue through peaceful means must conform to proposals made by the P5. ${ }^{43}$ The second one is resolution 2059(2012) on the situation in the Middle East. In this resolution, the absence of any reference to any previous Security Council

\footnotetext{
40 S.C. Res. 1988, pmbl., U.N. Doc. S/RES/1988 (June 17, 2011).

41 S.C. Res. 1904, supra note 28, $\uparrow 1$.

42 On the effectiveness of these sets of resolutions, see infra Part IV.

43 S.C. Res. 1929, supra note 29, pmbl., ๆ 32 (operative); see also S.C. Res. 1696, para. 4, U.N. Doc. S/RES/1696 (July 31, 2006).
} 
resolutions - either on the same subject-matter or related ones, as well as to international treaties - is striking.

\section{REUNITING "IS" AND “OUGHT"}

So far the analysis has shown that any attempts at assessing Security Council practice over a decade rely upon a particular vision of its role in addressing threats to or breaches of international peace and security. ${ }^{44}$ In particular, the previous Parts of this Article have examined what is the normative context stemming from selected provisions of the U.N. Charter and discussed the extent to which international law is able to shape Security Council practice with a view to finding coherence between theory and practice of Security Council powers. This Part aims to establish whether the proclaimed Security Council commitment to upholding applicable international law is tainted by appearance of bias. To that end, it creates a taxonomy of Security Council decisions adopted in a period of ten years (2004-2013) in order to find selection effects. The empirical analysis is based on simple statistics and includes actions adopted — namely, resolutions and PRSTs - as well as vetoes, inactions, and the outcome of private meetings.

In the period from 2004 to 2013, the Security Council adopted 1021 decisions, including 611 resolutions and 410 PRSTs. Grouped by categories of actions, the aggregated data shows that seventy-seven percent of all Security Council decisions address issues with a regional scope while sixteen percent of decisions address thematic issues. The remaining decisions, comprising seven percent, include actions previously agreed upon or taken by the broader family of United Nations institutions and seconded by the Security Council.

Figure 1: Composition of Security Council decisions (2004-2013)

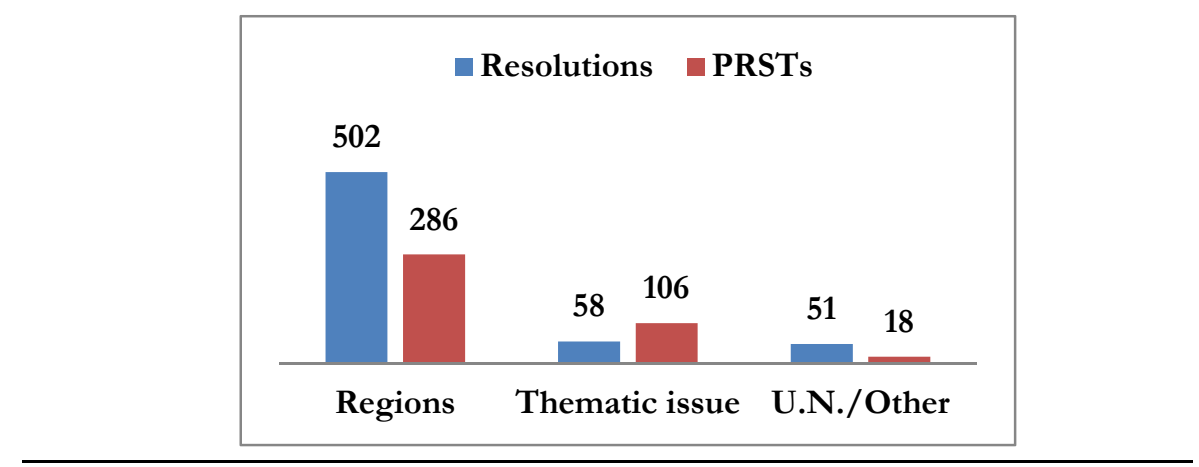

44 CheSTERMAN, FRANCK \& MALONE, supra note 1, at 575-96. 
The disaggregated data in the geopolitical section further demonstrates that 496 decisions-comprising forty-nine percent of all Security Council decisions, concern the African continent while 172 decisions-comprising seventeen percent, concern the Middle East region. ${ }^{45}$ Taken together, the number of Security Council decisions addressing issues taking place in Africa and the Middle East is equal to 668 out of 788 - comprising eighty-five percent of Security Council decisions on geopolitical regions. The figures do not take into consideration any decision addressing United Nations activities in those geopolitical areas (which have been classified as "U.N./Other" related issues), but only actions taken by the Security Council.

Figure 2: Composition of decisions on geopolitical regions (2004-2013)

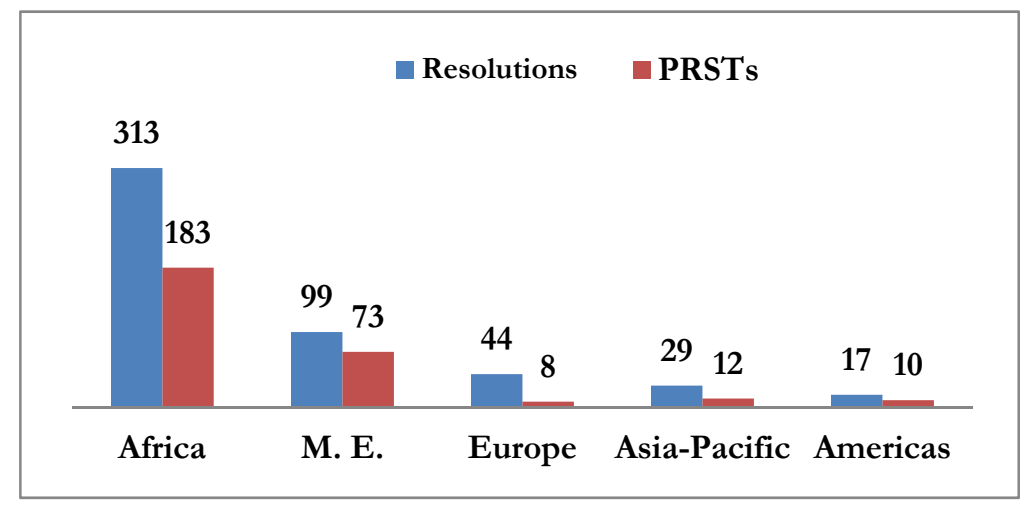

Table 3: Decisions on geopolitical regions (2004-2013)

\begin{tabular}{lll}
$\begin{array}{l}\text { Category of } \\
\text { action }\end{array}$ & All decisions & $\begin{array}{l}\text { Decisions on } \\
\text { geopolitical regions }\end{array}$ \\
Africa & $496(49 \%)$ & $496(63 \%)$ \\
Middle East & $172(17 \%)$ & $172(22 \%)$ \\
Europe & $52(5 \%)$ & $52(7 \%)$ \\
Asia-Pacific & $41(4 \%)$ & $41(5 \%)$ \\
Americas & $27(3 \%)$ & $27(3 \%)$ \\
\hline Tot. & 1021 & 788 \\
\hline
\end{tabular}

45 There is no generally accepted definition of Middle East. See Huseyin Yilmaz, The Eastern Question and the Ottoman Empire: The Genesis of the Near and Middle East in the Nineteenth Century, in Is THERE A Middle East? The Evolution of a Geopolitical Concept 11 (Michael E. Bonine, Abbas Amanat \& Michael E. Gasper eds., 2011). For the purposes of this article, the broadest concept is used. 
In light of the above, it is significant that sixty-six percent of all Security Council decisions adopted between 2004 and 2013 specifically target Africa and the Middle East whereas the remaining thirty-four percent address the remaining issues without giving prominence to any particular subject-matter. Assuming that the Security Council has not acted ultra vires,${ }^{46}$ the findings of the empirical analysis also suggest that the actions taken by the Security Council address situations representing threats to international peace and security, and, therefore, fall under the purview of its mandate. However, the major point of concern is that the margin of discretion of Security Council members in general, and the P5 in particular, reflects the scenario of international relations and diplomatic interactions between members of the international community. ${ }^{47}$ This, in turn, suggests that the actions taken by the Security Council in the period of time from 2004 to 2013 are tainted by selection bias. The number of Security Council meetings concluded without any action corroborates this conclusion, since the number of inactions related to geopolitical issues is equal to 753 out of 1040 , comprising seventy-three percent, and within this section, 622 inactions concern issues taking place in Africa and the Middle East, comprising eighty-three percent.

Figure 3: Composition of decisions on geopolitical regions (2004-2013)

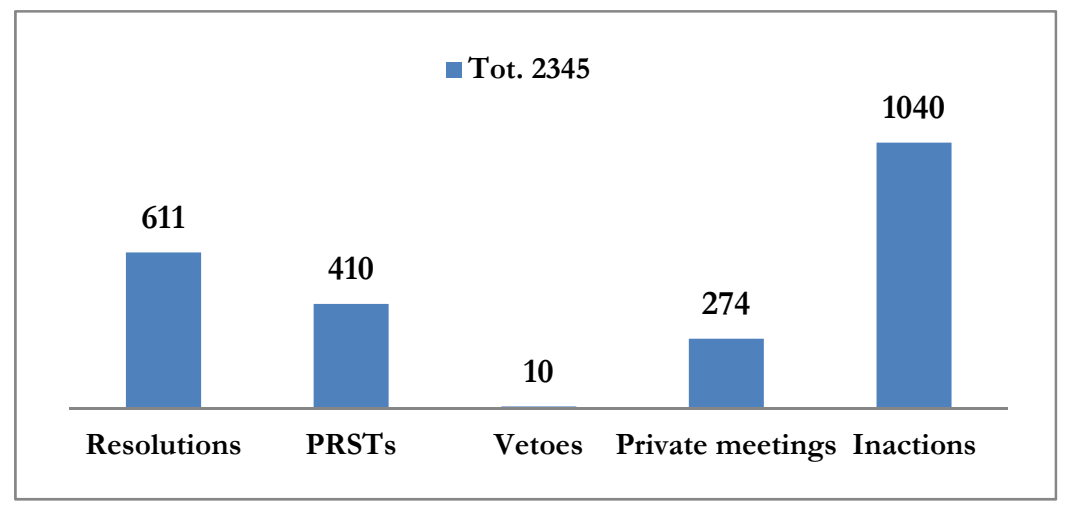

46 On this issue, see Rosand, supra note 2.

47 Henry J. Steiner \& Philip Alston, International Human Rights in COntext: Law, Politics, MORALS 651-53 (2000) (discussing gross violations of human rights and the Security Council's impasse caused by political convenience of the P5); see also RHONA K.M. SMITH, TEXTBOOK ON INTERNATIONAL HUMAN RIGHTS 54 (2010) (arguing that "[t]he most serious compliant raised against the Security Council is that it is less likely to take action against its permanent members"). 
Table 4: Decisions divided by categories of activities (2004-2013)

$\begin{array}{llll}\begin{array}{l}\text { Category of } \\ \text { activity }\end{array} & \text { Regions } & \begin{array}{l}\text { Thematic } \\ \text { issues }\end{array} & \text { U.N./Other } \\ \begin{array}{l}\text { Resolutions } \\ \text { PRSTs }\end{array} & 502 & 58 & 51 \\ \begin{array}{l}\text { Vetoes } \\ \text { Private meetings }\end{array} & 286 & 106 & 18 \\ \text { (statements) } & 75 & 0 & 0 \\ \text { Inactions } & 753 & 3 & 196^{*} \\ & & 157 & 130^{* *}\end{array}$

* Fig. includes 46 inactions related to the functioning of the Security Council

** Fig. includes 83 inactions related to the functioning of the Security Council

Overall, the numerical evidence yielded by this study shows that although individual Security Council decisions comply with the terms of its mandate, the selection of subject-matters representing the object of the decisions adopted between 2004 and 2013 ultimately amounts to a biased compliance with the U.N. Charter obligations. By assessing the implications of the results of data analysis on the internal and external coherence of current Security Council practice, the remainder of this Part explores the possibility to reunite what "is" and what "ought to be" current and future Security Council practice. ${ }^{48}$

The issue of external coherence refers to the relation between the Security Council and other U.N. organs-namely, the Secretary-General and the General Assembly. Previous studies have shown that because of the veto power, whether actual or threatened, certain decisions turn out to be impractical and have, therefore, suggested that alternative approaches and levels of discussion might help ameliorate the situation. ${ }^{49}$ For instance, the level of decision-making regarding threats to or breaches of international peace and security could be shared with other primary organs of the United Nations, at least at the preliminary stages of discussion leading to the possible inclusion of a matter on the Security Council agenda.

One such organ is the Secretary-General. As established practice shows, there is an ongoing exchange of letters between the Secretary-General and the

\footnotetext{
48 Joshua B. Fischman, Reuniting 'Is' and 'Ought' in Empirical Legal Scholarship, 162 U. PENN. L. REV. 117,168 (2013).

49 Deplano, supra note 16.
} 
Security Council President on current and potential issues on the Security Council agenda. ${ }^{50}$ However, although such an exchange is meant to improve the overall Security Council action strategy, the Security Council recognizes the role of the Secretary-General as merely consultative. ${ }^{51}$ In strict legal terms, this restrictive attitude of the Security Council stems from the wording of the U.N. Charter by virtue of Article 24, which confers "primary responsibility" on the Security Council for the maintenance of international peace and security. On the other side of the spectrum, Article 99 of the U.N. Charter may be invoked as the basis of the Secretary-General's political activities. ${ }^{52}$ It reads: "The Secretary-General may bring to the attention of the Security Council any matter which in his opinion may threaten the maintenance of international peace and security. ${ }^{, 53}$

Although formulated in broad terms, the right of the Secretary-General under Article 99 has limited relevance in constraining the powers of the Security Council. As the history of the drafting of Article 99 shows, the Secretary-General was not intended to preside over the Security Council or to dictate its agenda. ${ }^{54}$ By no coincidence, the final formulation of Article 99 was proposed by a P5, thus confirming the political nature of the Security Council. ${ }^{55}$

Another alternative might consist of a duty of the Security Council to take into consideration matters referred to it by the General Assembly and publicly justify its decisions as to whether or not take action in light of applicable provisions of the U.N. Charter and international law. As things stand, the General Assembly may discuss any questions relating to the maintenance of international peace and security and make any recommendations to Member States and the Security Council on any such questions. ${ }^{56}$ However, the rights of the General Assembly are subject to the provision of Article 12 of the U.N. Charter: "While the Security Council is exercising in respect of any dispute or situation the functions assigned to it in the present Charter, the General

50 Id. at $148-49$.

51 S.C. Res. 1998, supra note 29, $\mid 2$; S.C. Res. 1882, supra note 29, ๆ 2; S.C. Res. 1612, para. 4, U.N. Doc. S/RES/1612 (July 26, 2005); S.C. Pres. Statement 2010/10, para. 16, U.N. Doc. S/PRST/2010/10 (June $16,2010)$.

52 Edward Newman, Secretary-General, in WEISs \& DAws, supra note 1, at 177-78.

53 U.N. Charter art. 99.

54 Stephen M. Schwebel, The Origins and Development of Article 99 of the Charter, 28 BRIT. Y.B. INT'L L. 371 (1951).

55 Id. at 374.

56 U.N. Charter arts. 10-11. 
Assembly shall not make any recommendation with regard to that dispute or situation unless the Security Council so requests." ${ }^{, 57}$

Absent any duty of the Security Council to take into consideration situations of potential breach of international peace and security brought to its attention by other U.N. organs, such as the Secretary-General and the General Assembly, the possibility to create, and clarify, the normative parameter of legitimacy of Security Council actions is constantly jeopardized by the Security Council power to decide the degree of necessity of its intervention based on political considerations. ${ }^{58}$ Given the broad formulation of Article 24 of the U.N. Charter, even the principle laid out by the ICJ on the political character of an organ of the United Nations, such as the Security Council, cannot be regarded as decisive in determining the legitimacy of Security Council actions:

The political character of an organ cannot release it from the observance of the treaty provisions established by the Charter when they constitute limitations on its powers or criteria for its judgment. To ascertain whether an organ has freedom of choice for its decisions, reference must be made to the terms of its constitution. ${ }^{59}$

This has led certain international scholarship to conclude that "such lack of accountability and failure to provide remedies against an injudicious Security Council in itself poses a threat to international peace and security., 60

Perhaps the best way to establish a benchmark of international legality would be to ensure a high level of internal coherence of Security Council decisions. Resolutions and PRSTs addressing thematic issues, for example, could be used to set a parameter of legality for future Security Council actions. Such use of precedent would not be contrary to the Security Council mandate nor would it be perceived as an undue interference by the P5, since the content of thematic resolutions is decided by the Security Council itself. Conversely, it would bring benefit in the international legal system as it would start a process of codification of the legal mind of the Security Council. However, the

\footnotetext{
57 Id. art. 12.

58 In the Security Council resolutions and presidential statements on women, children and civilians there are countless references to the unlimited discretion of the Security Council in assessing matters brought to its attentions ("where necessary" and "on a case-by-case basis"). See, for instance, S.C. Pres. Statement 2002/6, U.N. Doc. S/PRST/2002/6 (Mar. 15, 2002).

59 Conditions of Admission of a State to Membership in the United Nations, 1948 I.C.J. 57, 64 (May 28, 1948) (emphasis added).

60 JAVAID REHMAN, INTERNATIONAL HUMAN RIGHTS LAW 39 (2010).
} 
effectiveness of this proposal is doubtful in many ways. In particular, whereas reasons of consistency and reasonableness of Security Council actions suggest that it is unlikely that the Security Council would treat identical situations in different ways without any serious justification, the definition of international peace and security is so broad that cannot eliminate selection bias relating to the issues included on the Security Council agenda.

\section{CONCLUSIONS}

The issue of interpretation of Security Council resolutions is highly contested. Scholars and international tribunals alike differ in their approach to the interpretation of the scope of individual resolutions, the determination of which clarifies their legal effect. ${ }^{61}$ By providing a systematic analysis of a sample comprising over a quarter of Security Council practice since 1946, this article has provided an alternative perspective.

The findings of the analysis show that the Security Council has developed a self-contained legal mind under the aegis of the U.N. Charter. Part III, in particular, has demonstrated that references to primary sources of international law in the text of resolutions abound, and they seem to have some influence on the behavioral patterns of the Security Council. However, as the adopted resolutions do not set a precedent, the sources of international law cited therein fail to establish an objective parameter of international legality. In addition, Part IV has shown that the powers of the Security Council are characterized by an inherent tension between compliance with the terms of its mandate and a degree of discretion related to the selection of subject-matters, which ultimately amounts to a biased compliance with its U.N. Charter obligations.

This leads to the conclusion that while the discretionary powers of the Security Council cannot be eliminated, its commitment to enhancing existent regimes of international law such as humanitarian law exercises some influence over its politics, as the case of the resolutions on women, children, and civilians demonstrate. At the same time, this constructive attitude of the Security Council contributes to strengthening the authority of existent rules and principles of international law. On the other side of the spectrum, it appears that, outside the area of international terrorism, the scrutinized

61 Sienho Yee, The Dynamic Interplay between the Interpreters of Security Council Resolutions, 11 CHINESE J. INT'L L. 613 (2012). 
behavioral regularities of the Security Council have little or no influence on the development of international law. 
APPENDIX 1-LIST OF RESOLUTIONS (2004-2013)

\begin{tabular}{|c|c|c|c|}
\hline Subject & $\begin{array}{l}\text { No. of } \\
\text { Res. }\end{array}$ & Category & Sub-category \\
\hline Admission of new members & 2 & U.N./Other & \\
\hline Afghanistan & 22 & Geopolitical regions & Middle East \\
\hline Bosnia and Herzegovina & 13 & Geopolitical regions & Europe \\
\hline Burundi & 14 & Geopolitical regions & Africa \\
\hline Central African Republic & 4 & Geopolitical regions & Africa \\
\hline $\begin{array}{l}\text { Chad, Central African } \\
\text { Republic and the sub- } \\
\text { region }\end{array}$ & 6 & Geopolitical regions & Africa \\
\hline $\begin{array}{l}\text { Children and armed } \\
\text { conflict }\end{array}$ & 5 & Thematic issue & \\
\hline $\begin{array}{l}\text { Cooperation between the } \\
\text { U.N. and regional and sub- } \\
\text { regional organizations in } \\
\text { maintaining international } \\
\text { peace and security }\end{array}$ & 2 & Thematic issue & \\
\hline Cyprus & 19 & Geopolitical regions & Europe \\
\hline $\begin{array}{l}\text { Date of election to fill a } \\
\text { vacancy in the ICJ }\end{array}$ & 4 & U.N./Other & \\
\hline $\begin{array}{l}\text { Democratic Republic of the } \\
\text { Congo }\end{array}$ & 41 & Geopolitical regions & Africa \\
\hline $\begin{array}{l}\text { General issues relating to } \\
\text { sanctions }\end{array}$ & 3 & Thematic issues & \\
\hline Georgia & 12 & Geopolitical regions & Europe \\
\hline Great Lakes Region & 2 & Geopolitical regions & Africa \\
\hline Guinea-Bissau & 7 & Geopolitical regions & Africa \\
\hline Haiti & 17 & Geopolitical regions & Americas \\
\hline ICTR & 16 & U.N./Other & \\
\hline ICTR and ICTY & 2 & U.N./Other & \\
\hline ICTY & 22 & U.N./Other & \\
\hline Iraq & 18 & Geopolitical regions & Middle East \\
\hline Ivory Coast & 47 & Geopolitical regions & Africa \\
\hline Letter from the permanent & 1 & Geopolitical regions & Asia \\
\hline
\end{tabular}




\begin{tabular}{|c|c|c|c|}
\hline $\begin{array}{l}\text { Representative of Japan to } \\
\text { the U.N. }\end{array}$ & & & \\
\hline $\begin{array}{l}\text { Letter from the Secretary- } \\
\text { General (S/2006/920) }\end{array}$ & 8 & Geopolitical regions & Asia \\
\hline Liberia & 33 & Geopolitical regions & Africa \\
\hline Libya & 7 & Geopolitical regions & Africa \\
\hline $\begin{array}{l}\text { Maintenance of } \\
\text { international peace and } \\
\text { security }\end{array}$ & 1 & Thematic issue & \\
\hline $\begin{array}{l}\text { Maintenance of } \\
\text { international peace and } \\
\text { security: nuclear non- } \\
\text { proliferation and nuclear } \\
\text { disarmament }\end{array}$ & 1 & Thematic issue & \\
\hline Mali & 3 & Geopolitical regions & Africa \\
\hline Middle East & 51 & Geopolitical regions & Middle East \\
\hline $\begin{array}{l}\text { Middle East, including the } \\
\text { Palestinian question }\end{array}$ & 3 & Geopolitical regions & Middle East \\
\hline Non-proliferation & 8 & Thematic issue & \\
\hline $\begin{array}{l}\text { Non- } \\
\text { proliferation/Democratic } \\
\text { People's Republic of Korea }\end{array}$ & 7 & Geopolitical regions & Asia \\
\hline Non-proliferation/Iran & 1 & Geopolitical regions & Middle East \\
\hline $\begin{array}{l}\text { Non-proliferation of } \\
\text { weapons of mass } \\
\text { destruction }\end{array}$ & 5 & Thematic issue & \\
\hline $\begin{array}{l}\text { Peace and security in } \\
\text { Africa }\end{array}$ & 7 & Geopolitical regions & Africa \\
\hline $\begin{array}{l}\text { Peace consolidation in West } \\
\text { Africa }\end{array}$ & 1 & Geopolitical regions & Africa \\
\hline Post-conflict peacebuilding & 3 & Thematic issue & \\
\hline $\begin{array}{l}\text { Protection of civilians in } \\
\text { armed conflicts }\end{array}$ & 3 & Thematic issue & \\
\hline $\begin{array}{l}\text { Recommendations for the } \\
\text { appointment of the } \\
\text { Secretary-General }\end{array}$ & 2 & U.N./Other & \\
\hline
\end{tabular}




\begin{tabular}{|c|c|c|c|}
\hline $\begin{array}{l}\text { Reports of the Secretary- } \\
\text { General on Sudan }\end{array}$ & 22 & Geopolitical regions & Africa \\
\hline Rwanda & 2 & Geopolitical regions & Africa \\
\hline $\begin{array}{l}\text { Security Council meetings } \\
\text { in Nairobi }\end{array}$ & 1 & U.N./Other & \\
\hline Sierra Leone & 14 & Geopolitical regions & Africa \\
\hline $\begin{array}{l}\text { Situation between Eritrea } \\
\text { and Ethiopia }\end{array}$ & 14 & Geopolitical regions & Africa \\
\hline $\begin{array}{l}\text { Situation between Iraq and } \\
\text { Kuwait }\end{array}$ & 4 & Geopolitical regions & Middle East \\
\hline $\begin{array}{l}\text { Small arms and light } \\
\text { weapons }\end{array}$ & 1 & Thematic issue & \\
\hline Somalia & 44 & Geopolitical regions & Africa \\
\hline Sudan & 25 & Geopolitical regions & Africa \\
\hline Sudan sanctions & 1 & Geopolitical regions & Africa \\
\hline Sudan/South Sudan & 4 & Geopolitical regions & Africa \\
\hline $\begin{array}{l}\text { Threats to international } \\
\text { peace and security } \\
\text { (Security Council Summit } \\
\text { 2005) }\end{array}$ & 2 & Thematic issue & \\
\hline $\begin{array}{l}\text { Threats to international } \\
\text { peace and security caused } \\
\text { by terrorist acts }\end{array}$ & 18 & Thematic issue & \\
\hline Timor Leste & 13 & Geopolitical regions & Asia \\
\hline $\begin{array}{l}\text { Tribute to the outgoing } \\
\text { Secretary-General }\end{array}$ & 1 & U.N./Other & \\
\hline $\begin{array}{l}\text { U.N. peacekeeping } \\
\text { operations }\end{array}$ & 1 & U.N./Other & \\
\hline Western Sahara & 15 & Geopolitical regions & Africa \\
\hline $\begin{array}{l}\text { Women and peace and } \\
\text { security }\end{array}$ & 6 & Thematic issue & \\
\hline Tot. & 611 & & \\
\hline
\end{tabular}


APPENDIX 2-LIST OF PRESIDENTIAL STATEMENTS (2004-2013)

\begin{tabular}{|l|c|l|l|}
\hline Subject \\
\begin{tabular}{|l|c|l|} 
No. of \\
PRSTs
\end{tabular} & Category & \\
\hline $\begin{array}{l}\text { Admission of new } \\
\text { members }\end{array}$ & 2 & U.N./Other & \\
\hline Afghanistan & 10 & Geopolitical regions & Middle East \\
\hline Bosnia and Herzegovina & 1 & Geopolitical regions & Europe \\
\hline $\begin{array}{l}\text { Briefings by chairmen of } \\
\text { Security Council } \\
\text { subsidiary bodies }\end{array}$ & 2 & U.N./Other & \\
\hline Burundi & & & \\
\hline Central African Region & 7 & Geopolitical regions & Africa \\
\hline $\begin{array}{l}\text { Central African } \\
\text { Republic }\end{array}$ & 5 & Geopolitical regions & Africa \\
\hline $\begin{array}{l}\text { Chad, Central African } \\
\text { Republic and the } \\
\text { subregion }\end{array}$ & 5 & Geopolitical regions & Africa \\
\hline Chad and Sudan & 3 & Geopolitical regions & Africa \\
\hline $\begin{array}{l}\text { Children and armed } \\
\text { conflict }\end{array}$ & 8 & Thematic issue & \\
\hline $\begin{array}{l}\text { Civilian aspects of } \\
\text { conflict: management } \\
\text { and peacebuilding }\end{array}$ & 1 & Thematic issue & \\
\hline $\begin{array}{l}\text { Cooperation between } \\
\text { the U.N. and regional } \\
\text { and sub-regional } \\
\text { organizations in } \\
\text { maintaining } \\
\text { international peace and } \\
\text { security }\end{array}$ & 4 & U.N./Other & \\
\hline $\begin{array}{l}\text { Cooperation between } \\
\text { the U.N. and regional } \\
\text { organizations in } \\
\text { stabilization processes }\end{array}$ & 1 & U.N./Other & \\
\hline $\begin{array}{l}\text { Cross-border issues in } \\
\text { West Africa }\end{array}$ & 2 & Geopolitical regions & Africa \\
\hline Cyprus & 3 & Geopolitical regions & Europe \\
\hline
\end{tabular}




\begin{tabular}{|c|c|c|c|}
\hline $\begin{array}{l}\text { Decision of Libya to } \\
\text { abandon its weapons of } \\
\text { mass destruction }\end{array}$ & 1 & & \\
\hline $\begin{array}{l}\text { Democratic Republic of } \\
\text { the Congo }\end{array}$ & 24 & Geopolitical regions & Africa \\
\hline Eritrea and Ethiopia & 7 & Geopolitical regions & Africa \\
\hline Great Lakes Region & 6 & Geopolitical regions & Africa \\
\hline Guinea-Bissau & 12 & Geopolitical regions & Africa \\
\hline Haiti & 10 & Geopolitical regions & Americas \\
\hline ICTR and ICTY & 2 & U.N./Other & \\
\hline $\begin{array}{l}\text { Institutional relationship } \\
\text { with the African Union }\end{array}$ & 1 & U.N./Other & \\
\hline Iraq & 7 & Geopolitical regions & Middle East \\
\hline Iraq and Kuwait & 3 & Geopolitical regions & Middle East \\
\hline Ivory Coast & 24 & Geopolitical regions & Africa \\
\hline $\begin{array}{l}\text { Justice and the rule of } \\
\text { law }\end{array}$ & 1 & Thematic issue & \\
\hline $\begin{array}{l}\text { Letter from Chargé } \\
\text { d'affaires of the } \\
\text { Permanent Mission of } \\
\text { Papua New Guinea }\end{array}$ & 1 & Geopolitical regions & Oceania \\
\hline $\begin{array}{l}\text { Letter from Permanent } \\
\text { Representative of Japan }\end{array}$ & 1 & Geopolitical regions & Africa \\
\hline $\begin{array}{l}\text { Letter from the } \\
\text { Permanent } \\
\text { Representative of Korea }\end{array}$ & 1 & U.N./Other & \\
\hline $\begin{array}{l}\text { Letter from Permanent } \\
\text { Representative of Sudan }\end{array}$ & 1 & Geopolitical regions & Africa \\
\hline $\begin{array}{l}\text { Letter from the } \\
\text { Secretary-General } \\
(\mathrm{S} / \mathbf{2 0 0 6 / 9 2 0 )}\end{array}$ & 3 & U.N./Other & \\
\hline Libya & 1 & Geopolitical regions & Africa \\
\hline $\begin{array}{l}\text { Maintenance of } \\
\text { international peace and } \\
\text { security }\end{array}$ & 6 & Thematic issue & \\
\hline $\begin{array}{l}\text { Maintenance of } \\
\text { international peace and } \\
\text { security: }\end{array}$ & 1 & Thematic issue & \\
\hline
\end{tabular}




\begin{tabular}{|c|c|c|c|}
\hline $\begin{array}{l}\text { interdependence } \\
\text { between security and } \\
\text { development }\end{array}$ & & & \\
\hline $\begin{array}{l}\text { Maintenance of } \\
\text { international peace and } \\
\text { security: mediation and } \\
\text { settlement of disputes }\end{array}$ & 2 & Thematic issue & \\
\hline $\begin{array}{l}\text { Maintenance of } \\
\text { international peace and } \\
\text { security: natural } \\
\text { resources and conflict }\end{array}$ & 1 & Thematic issue & \\
\hline $\begin{array}{l}\text { Maintenance of } \\
\text { international peace and } \\
\text { security: piracy }\end{array}$ & 1 & Thematic issue & \\
\hline $\begin{array}{l}\text { Maintenance of } \\
\text { international peace and } \\
\text { security: preventive } \\
\text { diplomacy }\end{array}$ & 1 & Thematic issue & \\
\hline $\begin{array}{l}\text { Maintenance of } \\
\text { international peace and } \\
\text { security: regulation and } \\
\text { reduction of armaments }\end{array}$ & 2 & Thematic issue & \\
\hline $\begin{array}{l}\text { Maintenance of } \\
\text { international peace and } \\
\text { security: role of Security } \\
\text { Council in supporting } \\
\text { security sector reform } \\
\end{array}$ & 2 & Thematic issue & \\
\hline $\begin{array}{l}\text { Maintenance of } \\
\text { international peace and } \\
\text { security: role of Security } \\
\text { Council in humanitarian } \\
\text { crises }\end{array}$ & 1 & Thematic issue & \\
\hline Middle East & 46 & Geopolitical regions & Middle East \\
\hline $\begin{array}{l}\text { Middle East, including } \\
\text { the Palestinian question }\end{array}$ & 7 & Geopolitical regions & Middle East \\
\hline Myanmar & 2 & Geopolitical regions & Asia \\
\hline Non-proliferation & 1 & Thematic issue & \\
\hline $\begin{array}{l}\text { Non- } \\
\text { proliferation/Democratic }\end{array}$ & 2 & Geopolitical regions & Asia \\
\hline
\end{tabular}




\begin{tabular}{|c|c|c|c|}
\hline $\begin{array}{l}\text { Peoples' Republic of } \\
\text { Korea }\end{array}$ & & & \\
\hline $\begin{array}{l}\text { Non-proliferation of } \\
\text { weapons of mass } \\
\text { destruction }\end{array}$ & 1 & Thematic issue & \\
\hline $\begin{array}{l}\text { Peace and security in } \\
\text { Africa }\end{array}$ & 17 & Geopolitical regions & Africa \\
\hline $\begin{array}{l}\text { Peace and security in } \\
\text { Africa: the Sahel region }\end{array}$ & 1 & Geopolitical regions & Africa \\
\hline $\begin{array}{l}\text { Peace consolidation in } \\
\text { West Africa }\end{array}$ & 5 & Geopolitical regions & Africa \\
\hline $\begin{array}{l}\text { Post-conflict national } \\
\text { reconciliation: role of } \\
\text { the United Nations }\end{array}$ & 1 & U.N./Other & \\
\hline $\begin{array}{l}\text { Post-conflict } \\
\text { peacebuilding }\end{array}$ & 6 & Thematic issue & \\
\hline $\begin{array}{l}\text { Post-conflict } \\
\text { peacebuilding: } \\
\text { institution-building }\end{array}$ & 1 & Thematic issue & \\
\hline $\begin{array}{l}\text { Protection of civilians in } \\
\text { armed conflicts }\end{array}$ & 6 & Thematic issue & \\
\hline $\begin{array}{l}\text { Relationship between } \\
\text { the United Nations and } \\
\text { regional and sub- } \\
\text { regional organizations in } \\
\text { the maintenance of } \\
\text { international peace and } \\
\text { security }\end{array}$ & 1 & Thematic issue & \\
\hline $\begin{array}{l}\text { Reports of the } \\
\text { Secretary-General on } \\
\text { Sudan }\end{array}$ & 26 & Geopolitical regions & Africa \\
\hline $\begin{array}{l}\text { Responsibility of the } \\
\text { Security Council in the } \\
\text { maintenance of } \\
\text { international peace and } \\
\text { security: HIV/AIDS and } \\
\text { peacekeeping operations }\end{array}$ & 1 & Thematic issue & \\
\hline $\begin{array}{l}\text { Role of civil society in } \\
\text { conflict prevention and }\end{array}$ & 1 & Thematic issue & \\
\hline
\end{tabular}




\begin{tabular}{|c|c|c|c|}
\hline $\begin{array}{l}\text { the pacific settlement of } \\
\text { disputes }\end{array}$ & & & \\
\hline $\begin{array}{l}\text { Role of regional and } \\
\text { sub-regional } \\
\text { organizations in the } \\
\text { maintenance of } \\
\text { international peace and } \\
\text { security }\end{array}$ & 1 & Thematic issue & \\
\hline Rule of law & 3 & Thematic issue & \\
\hline $\begin{array}{l}\text { Security Council } \\
\text { resolutions } 1160(1998), \\
1199(1998), 1203(1998), \\
1239(1999) \text { and } \\
1244(1999)\end{array}$ & 4 & Geopolitical regions & Europe \\
\hline Sierra Leone & 5 & Geopolitical regions & Africa \\
\hline Small arms & 3 & Thematic issue & \\
\hline Somalia & 24 & Geopolitical regions & Africa \\
\hline $\begin{array}{l}\text { Threats to international } \\
\text { peace and security }\end{array}$ & 3 & Thematic issue & \\
\hline $\begin{array}{l}\text { Threats to international } \\
\text { peace and security } \\
\text { caused by terrorist acts }\end{array}$ & 35 & Thematic issue & \\
\hline Timor Leste & 6 & Geopolitical regions & Asia \\
\hline $\begin{array}{l}\text { U.N. peacekeeping } \\
\text { operations }\end{array}$ & 5 & Thematic issue & \\
\hline $\begin{array}{l}\text { Women and peace and } \\
\text { security }\end{array}$ & 11 & Thematic issue & \\
\hline Tot. & 410 & & \\
\hline
\end{tabular}


APPENDIX 3-VETO LIST (2004-2013)

\begin{tabular}{|l|l|l|l|}
\hline Agenda item & Date & Draft & $\begin{array}{l}\text { Permanent member } \\
\text { casting negative vote }\end{array}$ \\
\hline $\begin{array}{l}\text { Middle East } \\
\text { situation, including } \\
\text { the Palestinian } \\
\text { question }\end{array}$ & $\begin{array}{l}\text { 25 March } \\
2004\end{array}$ & $\mathrm{~S} / 2004 / 240$ & United States \\
\hline Cyprus & 21 April 2004 & $\mathrm{S} / 2004 / 313$ & Russian Federation \\
\hline $\begin{array}{l}\text { Middle East } \\
\text { situation, including } \\
\text { the Palestinian } \\
\text { question }\end{array}$ & $\begin{array}{l}5 \text { October } \\
\text { 2004 }\end{array}$ & $\mathrm{S} / 2004 / 783$ & United States \\
\hline $\begin{array}{l}\text { Middle East } \\
\text { situation, including } \\
\text { the Palestinian } \\
\text { question }\end{array}$ & 13 July 2006 & $\mathrm{S} / 2006 / 508$ & United States \\
\hline Myanmar & 12 January & $\mathrm{S} / 2007 / 14$ & $\begin{array}{l}\text { China; Russian } \\
\text { Federation }\end{array}$ \\
\hline $\begin{array}{l}\text { Georgia } \\
\text { 2007 }\end{array}$ & 15 June 2009 & $\mathrm{S} / 2009 / 310$ & Russian Federation \\
\hline $\begin{array}{l}\text { Middle East } \\
\text { question } \\
\text { quation, including }\end{array}$ & 19 July 2012 & $\mathrm{S} / 2012 / 538$ & $\begin{array}{l}\text { China; Russian } \\
\text { Federation }\end{array}$ \\
\hline $\begin{array}{l}\text { Middle East } \\
\text { situation }\end{array}$ & $\begin{array}{l}\text { 4 October } \\
\text { 2011 }\end{array}$ & $\mathrm{S} / 2011 / 612$ & $\begin{array}{l}\text { China; Russian } \\
\text { Federation }\end{array}$ \\
\hline 4ituation: Syria & February & $\mathrm{S} / 2012 / 77$ & $\begin{array}{l}\text { China; Russian } \\
\text { Federation }\end{array}$ \\
\hline
\end{tabular}


Tot. 